\title{
Cytoprotective Effects of Geranylgeranylacetone against Retinal Photooxidative Damage
}

\author{
Masaki Tanito, ${ }^{1,2}$ Yong-Won Kwon, ${ }^{1}$ Norihiko Kondo, ${ }^{1}$ Jie Bai, ${ }^{1}$ Hiroshi Masutani, ${ }^{1}$ Hajime Nakamura, ${ }^{3}$ Junichi Fujii, ${ }^{4}$ \\ Akihiro Ohira, ${ }^{2}$ and Junji Yodoi ${ }^{1}$ \\ ${ }^{1}$ Department of Biological Responses, Institute for Virus Research, Kyoto University, Kyoto 606-8507, Japan, ${ }^{2}$ Department of Ophthalmology, Shimane \\ University School of Medicine, Shimane 693-8501, Japan, ${ }^{3}$ Thioredoxin Project, Department of Experimental Therapeutics, Translational Research Center, \\ Kyoto University Hospital, Kyoto 606-8507, Japan, and ${ }^{4}$ Department of Biochemistry, Yamagata University, Yamagata 990-9585, Japan
}

Exposure to excessive light induces retinal photoreceptor cell damage, leading to development and progression of various retinal diseases. We tested the effect of geranylgeranylacetone (GGA), an acyclic polyisoprenoid, on light-induced retinal damage in mice. Oral treatment with GGA $(1.0 \mathrm{mg} / \mathrm{d}$ ) for 5 d induced thioredoxin (Trx) and heat shock protein 72 (Hsp72) predominantly in the retinal pigment epithelium (RPE). After white light exposure (8000 lux for $2 \mathrm{~h}$ ), the percentage of terminal deoxynucleotidyl transferase-mediated biotinylated UTP nick end labeling-positive photoreceptor cells decreased significantly at 24 and $96 \mathrm{~h}$, and the number of photoreceptor cell nuclei at $96 \mathrm{~h}$ and the electroretinographic amplitudes of the a- and b-waves at 4 and $10 \mathrm{~d}$ increased significantly in GGA-pretreated mice compared with saline-pretreated mice. Light-induced upregulations of 8-hydroxy-2-deoxyguanosine and 4-hydroxy-2-nonenalmodified protein, markers of oxidative stress, were inhibited by GGA pretreatment. To elucidate the cytoprotective mechanism of GGA and Trx, we used human K-1034 RPE cells and mouse photoreceptor-derived 661W cells. In K-1034 cells, GGA (10 $\mu \mathrm{M})$ induced intracellular Trx, Hsp72, and extracellular Trx but not extracellular Hsp72. Extracellular Trx $(0.75 \mathrm{nM})$ attenuated $\mathrm{H}_{2} \mathrm{O}_{2}(200 \mu \mathrm{M})$-induced cell damage in $661 \mathrm{~W}$ cells. Pretreatment with GGA and overexpression of Trx in K-1034 cells counteracted $\mathrm{H}_{2} \mathrm{O}_{2}(50 \mu \mathrm{M})$-induced attenuation of cellular latex bead incorporation. Protection of phagocytotic activity through induction of Trx and possibly Hsp72 in RPE cells and elimination of oxidative stress in the photoreceptor layer through release of Trx from RPE cells may be mechanisms of GGA-mediated cytoprotection. Therefore, Trx is a neurotrophic factor released from RPE cells and plays a crucial role in maintaining photoreceptor cell integrity.

Key words: retinal light damage; geranylgeranylacetone; GGA; thioredoxin; Trx; heat shock protein 72; Hsp72; neurotrophic factor; phagocytosis

\section{Introduction}

Excessive light may enhance the development or progression of age-related macular degeneration and retinitis pigmentosa (Cruickshanks et al., 1993; Cideciyan et al., 1998), and light from operating microscopes used in ophthalmic practice can cause photic maculopathy (Byrnes et al., 1995). Light exposure induces photoreceptor cell death via apoptosis (Hafezi et al., 1997; Wenzel et al., 2000). Free radicals, including reactive oxygen species, play a crucial role in the damage (Organisciak et al., 1989; Ranchon et al., 2003).

Thioredoxin $(\operatorname{Trx})$ is a small $(13 \mathrm{kDa})$ ubiquitous protein with two redox-active cystine residues, -Cys-Gly-Pro-Cys-, in its active center (Holmgren, 1985). Human Trx was originally cloned as a soluble factor released from human $\mathrm{T}$ cell leukemia virus

Received July 30, 2004; revised Jan. 6, 2005; accepted Jan. 7, 2005.

This study was supported by a Grant-in-Aid for Research and Development Program for New Bio-Industry Initiatives. M.T. is a recipient of the Research Fellowships of the Japan Society for the Promotion of Science for Young Scientists. We are grateful to Akie Teratani, Ryoko Otsuki, and Yoshimi Yamaguchi for their technical assistance.

Correspondence should be addressed to Dr. Junji Yodoi, Institute for Virus Research, Kyoto University, 53 Shogoin-Kawaharacho, Sakyo, Kyoto 606-8507, Japan. E-mail: yodoi@virus.kyoto-u.ac.jp.

DOI:10.1523/JNEUROSCI.4866-04.2005

Copyright $\odot 2005$ Society for Neuroscience $\quad$ 0270-6474/05/252396-09\$15.00/0
type-I transformed T cells (Tagaya et al., 1989). Trx has various biologic activities, such as elimination of reactive oxygen species, activation of transcription factors, and regulation of the intracellular apoptotic pathway (Saitoh et al., 1998; Hirota et al., 1999), and is upregulated in response to a wide variety of oxidative stresses, including viral infections and ultraviolet and $\mathrm{x}$-ray irradiation (Nakamura et al., 1997). We reported previously that Trx is induced in the retinal pigment epithelial (RPE) layer after retinal ischemia-reperfusion injury in rats (Ohira et al., 1994). Current information suggests that imbalances in the tissue or cellular redox state are associated with light-induced photoreceptor cell damage (Tanito et al., 2002c), and normalization of the cellular redox state via intensification of endogenous (Tanito et al., 2002b) and exogenous (Tanito et al., 2002a) Trx expression prevents damage.

Heat shock protein 72 (Hsp72) increases in response to a variety of stresses, such as heat shock, hypoxia, hydrogen peroxide, inflammation, and ischemia (Ooie et al., 2001), and functions as a molecular chaperone to prevent protein aggregation and facilitate refolding of dysfunctional proteins critical to organ survival (Feldman and Frydman, 2000). Induction of Hsp72 in the neural retina by hyperthermia (Barbe et al., 1988) and intravitreous in- 
jection of Hsp72 protein (Yu et al., 2001) contribute to retinal protection against light damage.

Geranylgeranylacetone (GGA), an acyclic polyisoprenoid, is widely used as an anti-ulcer drug (Murakami et al., 1981). The cytoprotective effect of GGA is explained partly by induction of prostaglandins (PGs) (Terano et al., 1986). However, other studies reported that endogenous PGs are not involved in the action of GGA (Bilski et al., 1988); therefore, the molecular mechanism of the cytoprotective action of GGA is not fully understood. Recent information suggests that GGA increases Trx (Hirota et al., 2000; Dekigai et al., 2001; Bai et al., 2002) and Hsp expression (Hirakawa et al., 1996) in various cells and exerts cytoprotection.

To consider the strategy of intensification of Trx and Hsp72 for retinal protection, the use of an inducer for those proteins seems to be a less invasive and much safer way compared with pretreatment with hyperthermia, intraocular injection of proteins, and gene transfection. We evaluated whether GGA induces Trx and Hsp72 in retinal tissues in vivo and in vitro and how GGA mediates cytoprotection against retinal light damage.

\section{Materials and Methods}

Antibodies. Rabbit anti-mouse Trx antibody, mouse anti-human Trx antibody, and rabbit anti-murine peroxiredoxin (Prx)-I, -IV, and -VI antibodies have been described previously (Matsumoto et al., 1999; Fujii et al., 2001; Tanito et al., 2002b). Mouse anti-Hsp72 antibody was purchased from Stressgen Biotechnologies (Victoria, Canada). Mouse anti8-hydroxy-2-deoxyguanosine $(8 \mathrm{OHdG})$ monoclonal antibody and mouse anti-4-hydroxy-2-nonenal (4HNE)-modified protein monoclonal antibody were purchased from NOF Corporation (Tokyo, Japan).

Animal care. All procedures were performed according to the Association for Research in Vision and Ophthalmology Statement for the Use of Animals in Ophthalmic and Vision Research. Four-week-old male BALB/c mice were obtained from Japan SLC (Shizuoka, Japan) and maintained in our colony room for 5-7 d before the experiments. The light intensity in the colony room was $300 \mathrm{lux}$, and that within the cages was 20-40 lux. All mice were maintained under a $12 \mathrm{~h}$ (8:00 A.M. to 8:00 P.M.) light/dark cycle.

GGA treatment. GGA was obtained from Eisai (Tokyo, Japan). GGAtreated mice received $0.5 \mathrm{mg}$ of granulated GGA, suspended in $25 \mu \mathrm{l}$ of saline just before use. GGA was administered orally using a micropipette twice daily for $5 \mathrm{~d}$ before the experiment. GGA-untreated mice received $25 \mu \mathrm{l}$ of saline orally, twice daily, for $5 \mathrm{~d}$. For 8OHdG immunohistochemistry, morphometry, terminal deoxynucleotidyl transferasemediated biotinylated UTP nick end labeling (TUNEL), and electroretinograms (ERGs), mice that had not been exposed to light or treated with the study drug but dark adapted for $24 \mathrm{~h}$ also were studied as normal controls.

Western blotting for mouse Trx and Hsp72 in murine retinal samples. Eyes were enucleated $12 \mathrm{~h}$ after the final GGA treatment. The methods of obtaining retinal samples (neural retina and RPE cell fraction), preparation, and Western blotting were described previously (Tanito et al., 2002a). Both eyes of each mouse were pooled and used for analysis. Equal amounts of retinal protein (10 $\mu \mathrm{g}$ for Hsp72 and $5 \mu \mathrm{g}$ for mouse Trx) were electrophoresed on SDS-polyacrylamide gel (10\% for Hsp72 and $15 \%$ for mouse Trx). Band intensities were analyzed using the NIH Image software.

Light exposure. The procedure for light exposure has been reported previously (Hafezi et al., 1997; Tanito et al., 2002a). Light exposure began at 10:00 A.M., and the final treatment with GGA or saline was performed $12 \mathrm{~h}$ before the start of light exposure. The mice were dark adapted for $24 \mathrm{~h}$ before the experiments, and the pupils were dilated with $1 \%$ cyclopentolate hydrochloride eye drops (Santen, Osaka, Japan) $1 \mathrm{~h}$ before light exposure. The unanesthetized mice were exposed to 8000 lux of diffuse, cool, white fluorescent light (Matsushita Electric Industrial, Osaka, Japan) for $2 \mathrm{~h}$ in cages with a reflective interior. After light exposure, the mice were kept in the dark until the ERGs were recorded and enucleation.

Preparation of retinal tissue sections. The mice were perfused through
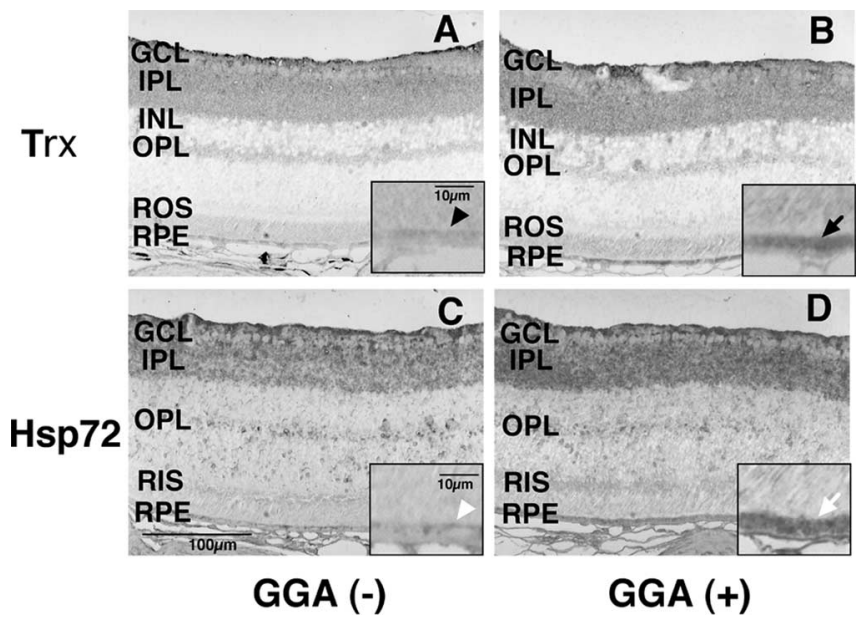

Figure 1. $\boldsymbol{A}-\boldsymbol{D}$, Representative immunohistochemistry for $\operatorname{Trx}(\boldsymbol{A}, \boldsymbol{B})$ and $H \mathrm{sp} 72(\boldsymbol{C}, \boldsymbol{D})$ in murine retina. $\boldsymbol{A}, \boldsymbol{B}$, Expression of Trx in the RPE layer of saline-treated mice $(\boldsymbol{A}$; arrowhead) and GGA-treated mice ( $\boldsymbol{B}$; arrow). $\boldsymbol{C}, \boldsymbol{D}$, Expression of Hsp72 in the RPE layer of saline-treated mice $(\boldsymbol{C}$; white arrowhead) and GGA-treated mice $(\boldsymbol{D}$; arrow). The results are representative of three independent experiments. INL, Inner nuclear layer; OPL, outer plexiform layer; RIS, rod inner segments; ROS, rod outer segments.

\section{A RPE FRACTION}
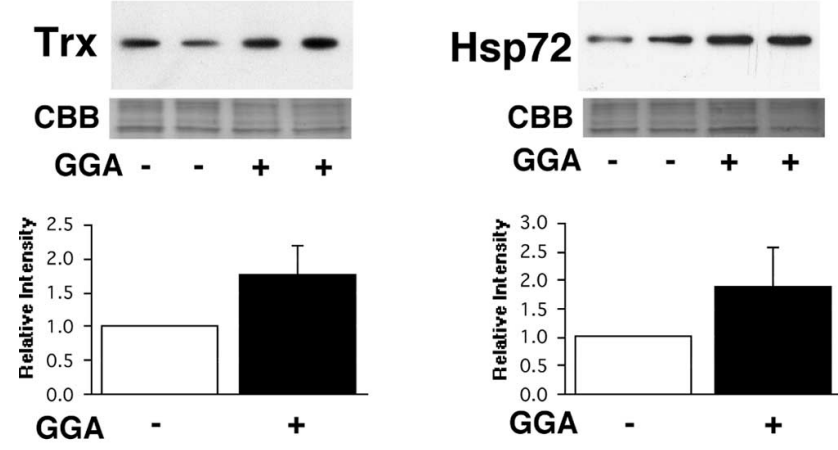

\section{B NEURAL RETINA}
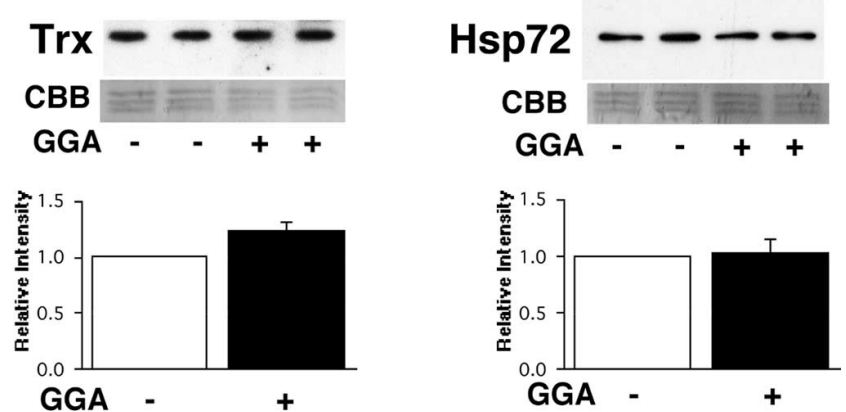

Figure 2. Western blotting for Trx and Hsp72 in murine retinal samples. $\boldsymbol{A}$, Expression of Trx and Hsp72 in GGA-untreated [GGA(-)] and GGA-treated [GGA(+)] mice in RPE fraction. $\boldsymbol{B}$, Expression of Trx and Hsp72 in GGA-untreated [GGA(-)] and GGA-treated [GGA(+)] mice in the neural retina. Samples from two independent mice in each group were analyzed by Western blotting in each experiment. The experiments were repeated three times, and the band intensities of GGA + samples relative to GGA - samples are shown in the bar graph (mean \pm SD; $n=6)$. Sample loading was monitored by staining with Coomassie Brilliant Blue R-250 (CBB).

the left cardiac ventricle with PBS and then perfused with freshly prepared $4 \%$ paraformaldehyde containing $0.25 \%$ glutaraldehyde in PBS. A 7-0 silk suture was placed as a landmark at the temporal side of the right eye and then the right eye was removed. The eyes were fixed in the same 
fixative for $12 \mathrm{~h}$ at $4^{\circ} \mathrm{C}$ and embedded in paraffin. One micrometer sagittal sections containing the whole retina, including the optic disc, were cut for immunohistochemistry, morphometry, and TUNEL.

Immunohistochemistry for mouse $\operatorname{Tr} x, H s p 72$, Prx-I, Prx-IV, Prx-VI, 8OHdG, and 4HNEmodified proteins in retinal sections. The eyes were enucleated $12 \mathrm{~h}$ after the final treatment with GGA or saline for immunohistochemical analysis for mouse Trx and Hsp72, and $24 \mathrm{~h}$ after light exposure for $8 \mathrm{OHdG}$ and $4 \mathrm{HNE}-$ modified protein. For Prx-I, -IV, and -VI, the untreated normal control mice were analyzed.

For mouse Trx, Hsp72, 4HNE-modified protein, Prx-I, Prx-IV, and Prx-VI, an immunoperoxidase technique was used (Tanito et al., 2002a). Briefly, endogenous peroxidase activity was inactivated with $0.6 \% \mathrm{H}_{2} \mathrm{O}_{2}$. The primary antibody or control normal serum was added and incubated at $4^{\circ} \mathrm{C}$ overnight. Biotinylated goat IgG (Biomeda, Foster City, CA), antimouse for Hsp72 and 4HNE-modified protein, and anti-rabbit for Trx, Prx-I, Prx-IV, and Prx-VI were used as the secondary antibody. Avidin-biotin amplification (Biomeda) was performed, which was followed by incubation with the substrate $0.1 \% 3^{\prime}, 3^{\prime}$-diaminobenzidine (Dako, High Wycombe, UK).

For $8 \mathrm{OHdG}$, the alkaline-phosphatase technique was used (Tanito et al., 2002c). After the sections were autoclaved in $10 \mathrm{mmol} / \mathrm{L}$ citrate buffer, $\mathrm{pH}$ 6.0, the primary antibody or normal mouse serum was added and incubated at $4^{\circ} \mathrm{C}$ overnight. Biotin-labeled rabbit anti-mouse IgG (Dako) was used as the second antibody, followed by an avidin-biotin-alkaline phosphatase complex (Vector Laboratories, Burlingame, CA).

Morphometry. The right eye was enucleated 24 and $96 \mathrm{~h}$ after light exposure, and retinal sections were stained with hematoxylin-eosin. Digitized color images of four locations (two in the superior retina $100-800 \mu \mathrm{m}$ above the optic disc and two in the inferior retina $100-800$ $\mu \mathrm{m}$ below the optic disc) were obtained for each section using a Digital Imaging system (PDMC le; Olympus, Tokyo, Japan). The number of hematoxylin-positive photoreceptor cell nuclei in each image was counted (Tanito et al., 2002a) and compared between the GGAtreated and -untreated mice.

TUNEL. The right eye was enucleated 24 and $96 \mathrm{~h}$ after light exposure, and TUNEL was performed using an in situ Apoptosis Detection kit (Takara, Kusatsu, Japan) on an obtained section. 3', 3'-diaminobenzidine (Dako) was used as chromogen. The percentage of TUNELpositive photoreceptor cell nuclei was estimated in the same locations described above (Tanito et al., 2002a) and compared between GGA-treated and -untreated mice.

ERGs. Four and $10 \mathrm{~d}$ after light exposure, flash ERGs were recorded (PE-3000; Tomey, Nagoya, Japan) by methods described previously (Tanito et al., 2002c). Thirty minutes before the recording, the animals were anesthetized with pentobarbital $(20 \mathrm{mg} / \mathrm{kg}$, intraperitoneally), and the pupils were dilated with $0.5 \%$ tropicam-
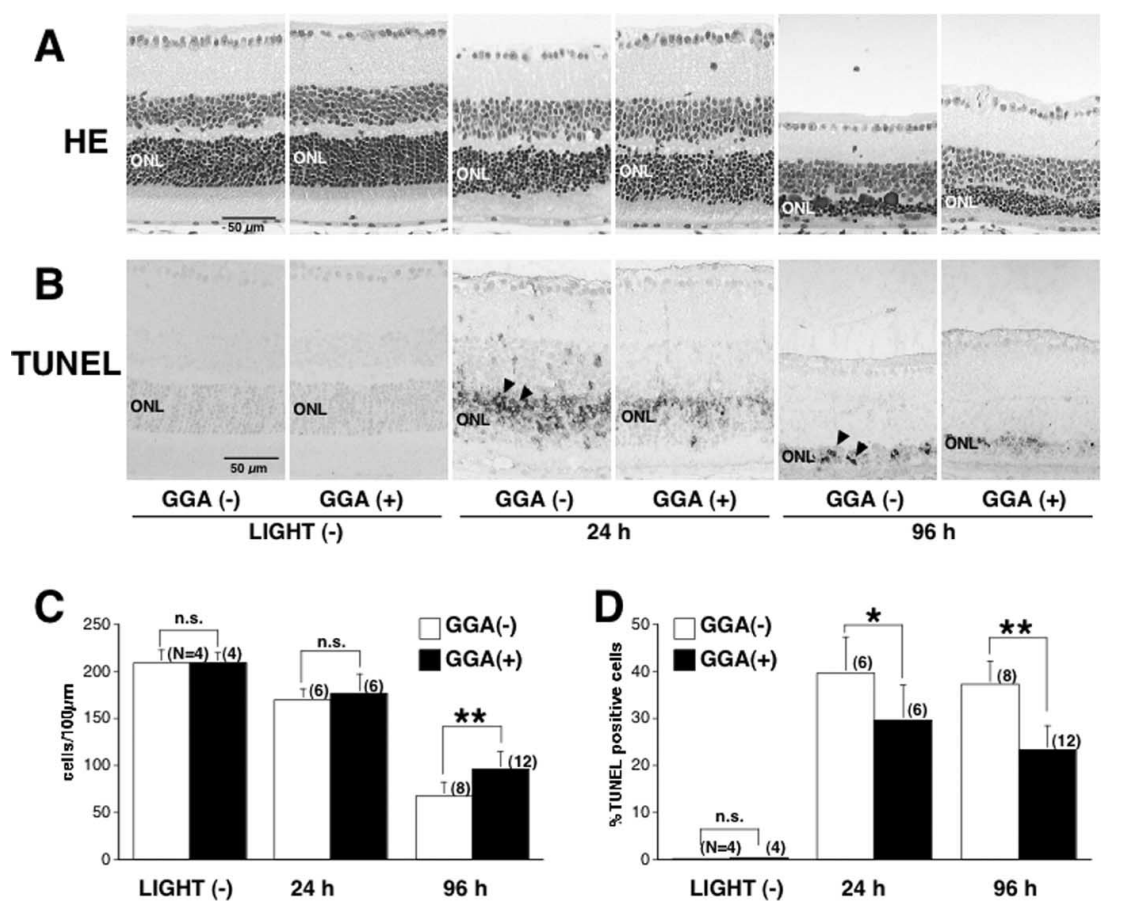

Figure 3. Numbers of photoreceptor cell nuclei and percentages of TUNEL-positive cells in the ONL 24 and $96 \mathrm{~h}$ after light exposure. $\boldsymbol{A}, \boldsymbol{B}$, Hematoxylin-eosin (HE) staining $(\boldsymbol{A})$ and TUNEL staining $(\boldsymbol{B})$ of retinal specimens from mice not exposed to light (first and second panels) and from mice $24 \mathrm{~h}$ (panels 3 and 4 ) and $96 \mathrm{~h}$ (panels 5 and 6 ) after light exposure. Mice were pretreated with GGA (panels 2, 4, and 6) or saline (panels 1, 3, and 5). TUNEL-positive cells are observed in the ONL after light exposure (arrowheads). C, D, Quantification of the number of photoreceptor cell nuclei $(\boldsymbol{C})$ and percentage of TUNEL-positive cells $(\boldsymbol{D})$. $^{*} p<$ 0.05 and ${ }^{* *} p<0.001$ by unpaired $t$ test comparison of the GGA-untreated and GGA-treated mice. Each bars are expressed as mean \pm SD.

A

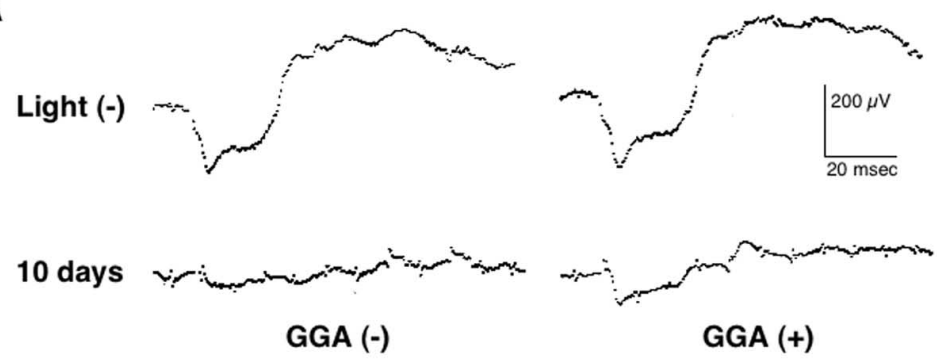

B
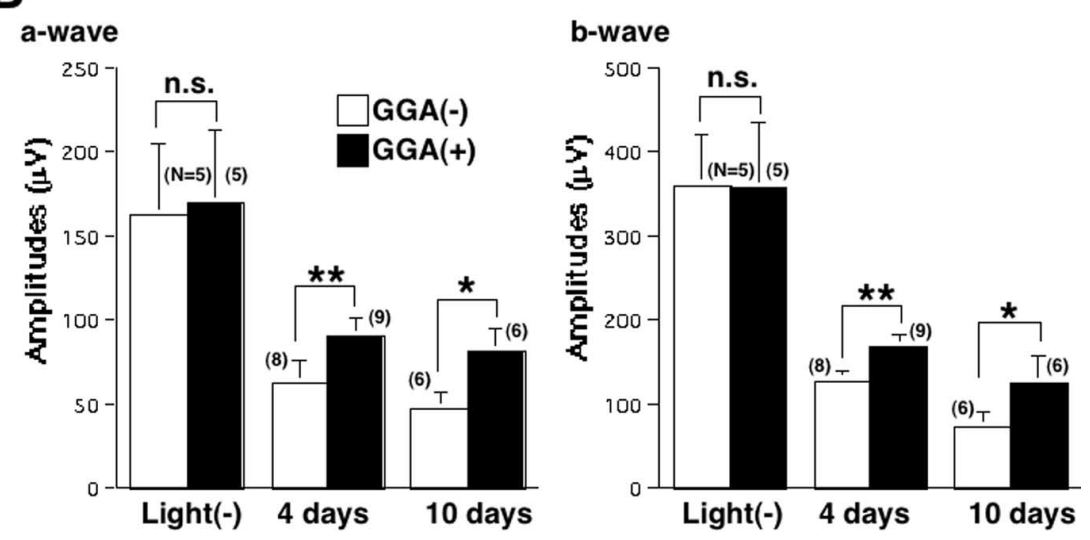

Figure 4. ERGs 4 and $10 \mathrm{~d}$ after light exposure. $\boldsymbol{A}$, Representative ERG recordings before (top) and $10 \mathrm{~d}$ after (bottom) light exposure from GGA-untreated (left) and GGA-treated (right) mice. $\boldsymbol{B}$, The a-wave (left) and b-wave (right) amplitudes are significantly higher in GGA-treated mice compared with GGA-untreated mice 4 and $10 \mathrm{~d}$ after light exposure $\left({ }^{*} p<0.01\right.$ and ${ }^{* *} p<$ 0.001 by unpaired $t$ test). Each bar is expressed as mean \pm SD. 
A
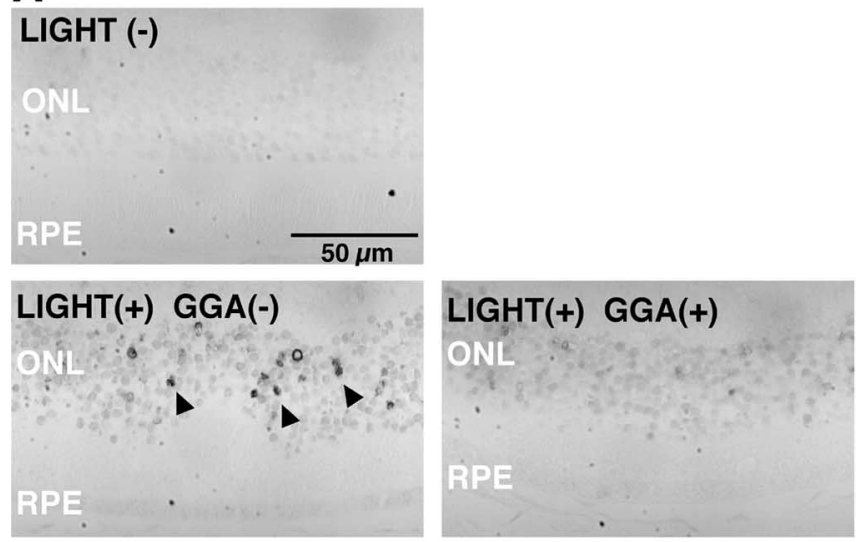

B
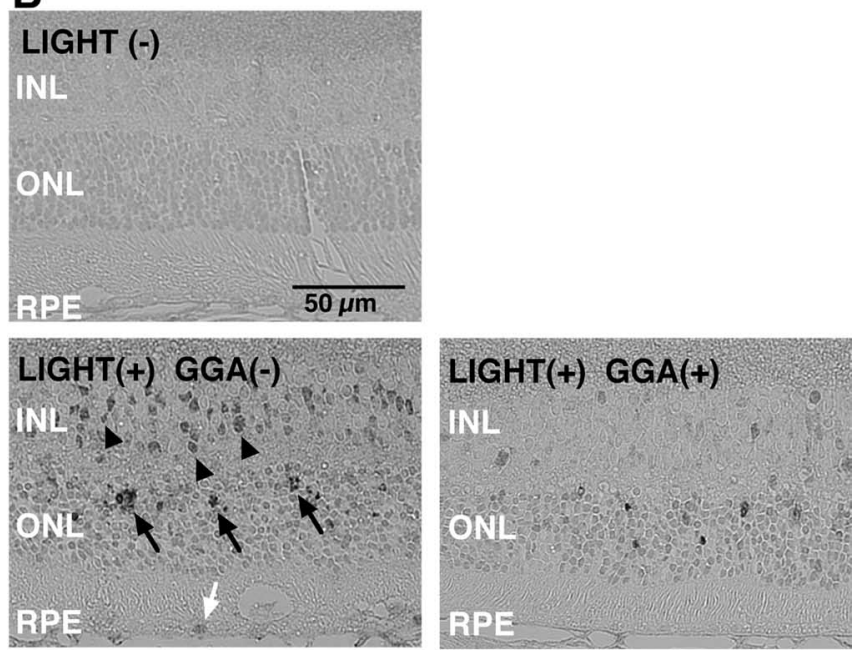

Figure 5. Representative immunohistochemistry for $80 \mathrm{HdG}(\boldsymbol{A})$ and $4 \mathrm{HNE}-$ modified protein $(\boldsymbol{B})$ in murine retina. $\boldsymbol{A}$, In specimens from mice not exposed to light (top), no labeling or slight labeling of $80 \mathrm{HdG}$ is observed. Twenty-four hours after light exposure, labeling intensity increases in most nuclei of the ONL, and some cells show strong labeling (arrowheads) in specimens from mice not treated with GGA (GGA-) (bottom left), but fewer cells are seen in specimens from GGA-treated mice (bottom right). $\boldsymbol{B}$, In specimens from mice not exposed to light (top), no labeling or slight labeling of 4HNE-modified protein is observed. Twenty-four hours after light exposure, labeling intensity increases throughout the retina, and some cells show strong perinuclear or nuclear labeling in the inner nuclear layer (INL) (arrowheads), 0NL (arrows), and RPE (white arrow) in specimens from mice not treated with GGA (GGA-) (bottom left), but fewer cells are seen in specimens from GGA-treated mice (bottom right).

ide and $0.5 \%$ phenylephrine hydrochloride eye drops (Santen). A contact lens gold electrode ( $3 \mathrm{~mm}$ diameter, $1.5 \mathrm{~mm}$ base curve; Kyoto Contact Lens, Kyoto, Japan) was placed on the left eye. An identical reference electrode was placed in the mouth, and a ground electrode was placed on the left footpad. A single flash of light (duration, $20 \mathrm{~ms}$ ) from a halogen source $30 \mathrm{~cm}$ from the eye was used as the light stimulus. The mean a- and b-wave amplitudes obtained from the GGA-treated and -untreated mice were compared.

Cell culture. Human K-1034 RPE cells (Gauntt et al., 1994; Kigasawa et al., 1994) and mouse photoreceptor-derived 661W cells (Tan et al., 2004), which were kindly provided by Dr. Al-Ubaidi (Department of Cell Biology, University of Oklahoma Health Sciences Center, Oklahoma City, OK), were maintained in Ham's F-12 medium and DMEM, respectively, containing 10\% fetal bovine serum, $100 \mathrm{U} / \mathrm{ml}$ penicillin, and 100 $\mu \mathrm{g} / \mathrm{ml}$ streptomycin in $5 \% \mathrm{CO}_{2}$ at $37^{\circ} \mathrm{C}$.

Western blotting for human TRX and Hsp72 in GGA-treated K-1034 RPE cells and its culture medium and for Prx-I, Prx-IV, and Prx-VI in $661 W$ cells. K-1034 cells $\left(5 \times 10^{5}\right.$ cells) were cultured with $3 \mathrm{ml}$ of medium on $6 \mathrm{~cm}$ culture dishes and treated with GGA (1 or $10 \mu \mathrm{M}$ ) for 24 and $48 \mathrm{~h}$. For in vitro experiments, a stock solution of GGA dissolved in ethanol was used (Hirota et al., 2000). The final concentration of ethanol in culture medium was $<0.1 \%$, and the accompanying control cells were treated with the same amount of ethanol. After incubation with GGA, the culture medium and cells were collected.

Total cell lysate was prepared as described previously (Kwon et al., 2002). The culture medium was concentrated using methanol precipitation methods. Briefly, culture medium to which was added five times the volume of ice-cold methanol was stored at $-20^{\circ} \mathrm{C}$ overnight and centrifuged at $12,000 \times g$ for $20 \mathrm{~min}$. The supernatant was then discarded, and the pellet was suspended in SDS sample buffer. For Hsp72, the albumin and immunoglobulin contents of the culture medium were removed using a ProteoExtract Albumin/IgG Removal kit (Calbiochem, La Jolla, CA) before the methanol precipitation. Equal amounts of total cell lysate ( $5 \mu \mathrm{g}$ of protein for human Trx and $15 \mu \mathrm{g}$ of protein for Hsp72) or concentrated proteins from the culture medium (concentrates from 125 $\mu \mathrm{l}$ of medium for human Trx and $250 \mu \mathrm{l}$ of medium for Hsp72) were electrophoresed on SDS polyacrylamide gel (15\% for human Trx and $7.5 \%$ for Hsp72). Specific bands then were detected according to the method of Western blotting as described previously. Total cell lysates (30 $\mu \mathrm{g})$ of $661 \mathrm{~W}$ cells were electrophoresed on $10 \%$ SDS polyacrylamide gel, and the specific bands for Prx-I, -IV, and -VI were detected as described previously.

Sandwich ELISA for human TRX in culture medium of GGA-treated K-1034 RPE cells. Nonconcentrated culture medium $(20 \mu \mathrm{l})$ of GGAtreated K-1034 cells described previously was analyzed with sandwich ELISA for human Trx. A human Trx ELISA kit was purchased from Redox Bioscience (Kyoto, Japan), the details of which were described previously (Nakamura et al., 2001).

Lactate dehydrogenase releasing assay in $\mathrm{H}_{2} \mathrm{O}_{2}$-treated $661 \mathrm{~W}$ cells. $\mathrm{Re}$ combinant human (rh) Trx was purchased from Ajinomoto (Tokyo, Japan). The $661 \mathrm{~W}$ cells $\left(5 \times 10^{3}\right.$ cells $)$ were cultured with $0.2 \mathrm{ml}$ of medium on a 96-well culture plate and treated with $\mathrm{H}_{2} \mathrm{O}_{2}(200 \mu \mathrm{M})$ with $\operatorname{rhTrx}(0,0.75,7.5$, and $75 \mathrm{~nm})$ added to the culture medium. After $48 \mathrm{~h}$ $50 \mu \mathrm{l}$ of culture medium was analyzed using a lactate dehydrogenase (LDH)-releasing assay kit (Roche, Tokyo, Japan) to estimate cellular damage. The percentage of cell death was calculated from $0 \%$ cell death (medium only) to $100 \%$ cell death (cells treated with $2 \%$ Triton X-100).

Overexpression of green fluorescent protein-Trx fusion protein in K-1034 cells. The DNA fragments encoding human Trx (Kondo et al., 2004) were amplified by PCR and inserted between the BglII and the XbaI sites of the pEGFP-C1 vector (Clontech, Palo Alto, CA). The K-1034 cells were transfected with human Trx-pEGFP-C1 vector using Fu-GENE 6 (Roche) following the instructions of the manufacturer. After transfection, the cells were cultured with fresh medium containing $1 \mathrm{mg} / \mathrm{ml}$ neomycin (G418; Nacalai Tesque, Kyoto, Japan) for 2 weeks, and pooled transfectants were used for subsequent experiments.

Phagocytotic activity of K-1034 cells. K-1034 cells $\left(5 \times 10^{2}\right.$ cells $/ 3 \mathrm{ml}$ of medium on a $3 \mathrm{~cm}$ dish), pretreated with or without GGA (10 $\mu \mathrm{M})$ for $24 \mathrm{~h}$, or pooled green fluorescent protein (GFP)-human Trxoverexpressing K-1034 cells $\left(5 \times 10^{2}\right.$ cells $/ 3 \mathrm{ml}$ of medium on a $3 \mathrm{~cm}$ dish) were treated with a sublethal dose of $\mathrm{H}_{2} \mathrm{O}_{2}(50 \mu \mathrm{M})$ for $24 \mathrm{~h}$. The cells then were treated with $0.2 \mu \mathrm{l}$ of a red fluorescent carboxylatemodified latex beads solution ( $1 \mu \mathrm{m}$ diameter, 2.5\% solid; L3155; Sigma, St. Louis, MO) for another $48 \mathrm{~h}$. Incorporation of latex beads into the cell body was observed using a fluorescence microscope (DP70 Digital Imaging system; Olympus) and was quantified as FL-2 fluorescence intensity by flow cytometry (FACS Calibur; Becton Dickinson, Tokyo, Japan) using CELLQUEST software with the modified methods of a previous study (Goncalves et al., 2003). The ability to incorporate latex beads into K-1034 cells has been reported previously (Gauntt et al., 1994; Kigasawa et al., 1994).

\section{Results}

Immunohistochemical analysis (Fig. 1) showed clear upregulation of Trx (Fig. 1B) and Hsp72 (Fig. 1D) in the RPE layer of mice treated with GGA $(0.5 \mathrm{mg}$, twice each day for $5 \mathrm{~d})$ compared with those treated with saline only (Fig. $1 A, C$, respectively). A slight increase in Hsp 72 labeling was observed in the ganglion cell layer 
(GCL) and inner plexiform layer (IPL) in GGA-treated murine retina (Fig. 1D). Western blotting also showed induction of TRX and Hsp72 in RPE (Fig. 2A). In the neural retina (Fig. 2B), Trx was upregulated slightly, whereas Hsp72 was not upregulated by GGA.

Ninety-six hours after light exposure, the number of cell nuclei in the outer nuclear layer (ONL) was significantly higher (Fig. $3 A, C$ ) in GGA-treated mice compared with saline-treated mice. Twenty-four and $96 \mathrm{~h}$ after light exposure, the percentage of TUNEL-positive cells in the ONL was significantly lower (Fig. 3B,D) in GGA-treated mice compared with saline-treated mice. ERGs were recorded before and 4 and $10 \mathrm{~d}$ after light exposure to estimate retinal function (Fig. $4 A, B$ ). Before light exposure, there was no difference in the $a-$ and $b$-wave amplitudes between GGA-untreated and -treated mice. Four and $10 \mathrm{~d}$ after light exposure, the a- and b-wave amplitudes were significantly higher in mice pretreated with GGA compared with those treated with saline only. To estimate the levels of oxidative stress, immunohistochemical analyses for $8 \mathrm{OHdG}$ and $4 \mathrm{HNE}$-modified protein, established markers for oxidative stress-induced DNA damage (Toyokuni et al., 1997) and lipid peroxidation (Toyokuni et al., 1994), respectively, were performed in retinal specimens. Twenty-four hours after light exposure, labeling intensities for $8 \mathrm{OHdG}$ in the ONL (Fig. 5A) and for $4 \mathrm{HNE}$ in the INL and ONL (Fig. 5B) were remarkably higher in mice treated with saline only compared with GGA-pretreated mice. Those results indicated that oral pretreatment of GGA attenuates light-induced photoreceptor cell damage in mice. To test the mechanisms of GGA-mediated cytoprotection against light damage, an additional analysis was performed.

Human K-1034 RPE cells were treated with GGA, and Trx and Hsp72 then were detected in total cell lysate and culture medium. Western blotting showed that Trx and Hsp72 were upregulated in cell lysate depending on the GGA concentration (Fig. 6A). In culture medium, Trx but not Hsp72 was detected, and the amount of Trx increased after GGA treatment (Fig. 6B). This GGA-induced increase of Trx secretion from RPE cells also was detected with sandwich ELISA for Trx (Fig. 6C).

We tested the effect of rhTrx protein against $\mathrm{H}_{2} \mathrm{O}_{2}$-induced $661 \mathrm{~W}$ photoreceptor cell damage using an $\mathrm{LDH}$-releasing assay. Cell damage caused by $\mathrm{H}_{2} \mathrm{O}_{2}$ was remarkably attenuated by the rhTrx in the culture medium (Fig. 6D). We tested the Prx family protein expression in cultured $661 \mathrm{~W}$ cells and mouse retina. Western blotting showed that Prx-I, -IV, and -VI were detected in the cell lysate of 661W cells (Fig. 6E). By immunohistochemical analysis, labeling for Prx-I, -IV, and -VI was commonly observed in several retinal layers, including the rod outer segments and RPE (Fig. 7).

Phagocytosis is a primary function of RPE cells for maintaining retinal photoreceptor integrity. We tested the effect of GGA
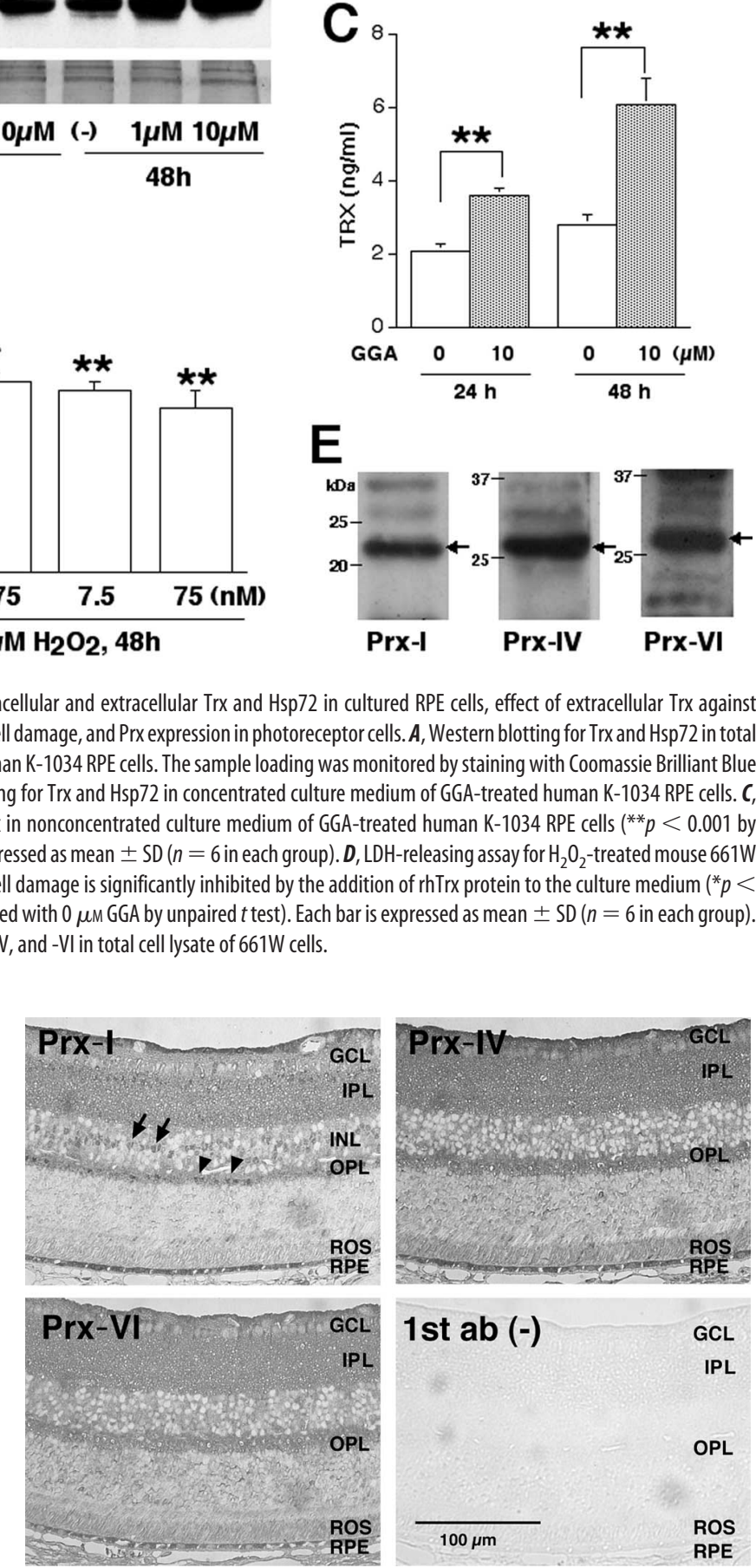

Hsp72 cell
lysate $\frac{\text { Oh } 24 \mathrm{~h} 48 \mathrm{~h}}{\text { GGA } 10 \mu \mathrm{M}}$
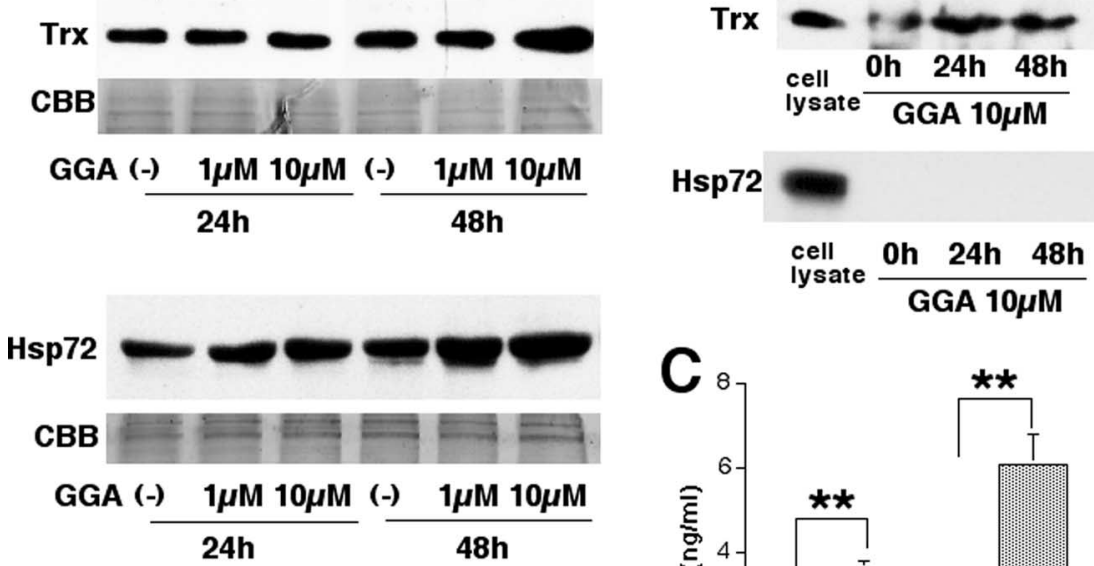

Figure 6. Detection of intracellular and extracellular Trx and Hsp72 in cultured RPE cells, effect of extracellular Trx against $\mathrm{H}_{2} \mathrm{O}_{2}$-induced photoreceptor cell damage, and Prx expression in photoreceptor cells. A, Western blotting for Trx and Hsp72 in tota 0.01 and ${ }^{* *} p<0.001$, compared with $0 \mu \mathrm{M}$ GGA by unpaired $t$ test). Each bar is expressed as mean $\pm S D$ ( $n=6$ in each group). $E$, Western blotting for Prx-I, -IV, and -VI in total cell lysate of 661W cells.

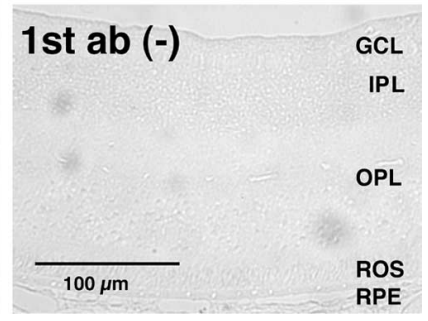

Figure 7. Immunohistochemistry of Prx-I,-IV, and-Vlinmouseretina.Clearexpression of Prx-I(topleft), Prx-IV (top right), and Prx-VI (bottom left) are observed in the GCL, IPL, outer plexiform layer (OPL), rod outer segment (ROS), and RPE. Nuclear staining of the Prx-lis observed in the inner nuclear layer (INL; arrows) and OPL (arrowheads).1stab, (-), Omitted the firstantibodies as a negative control. 
A
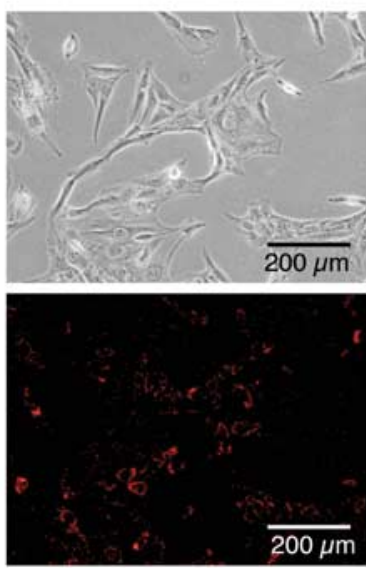

$\mathrm{H}_{2} \mathrm{O}_{2}(-)$

B

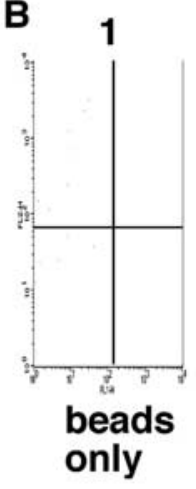

2
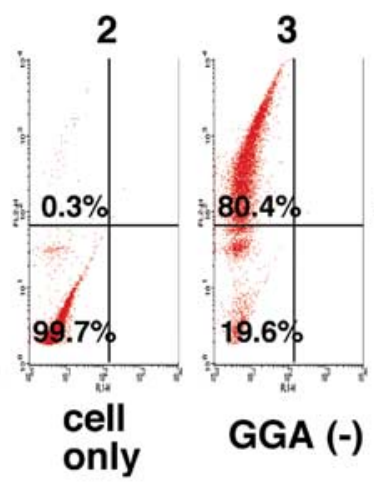

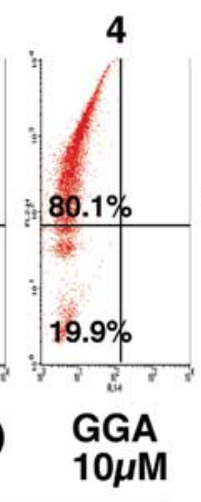

cell + beads
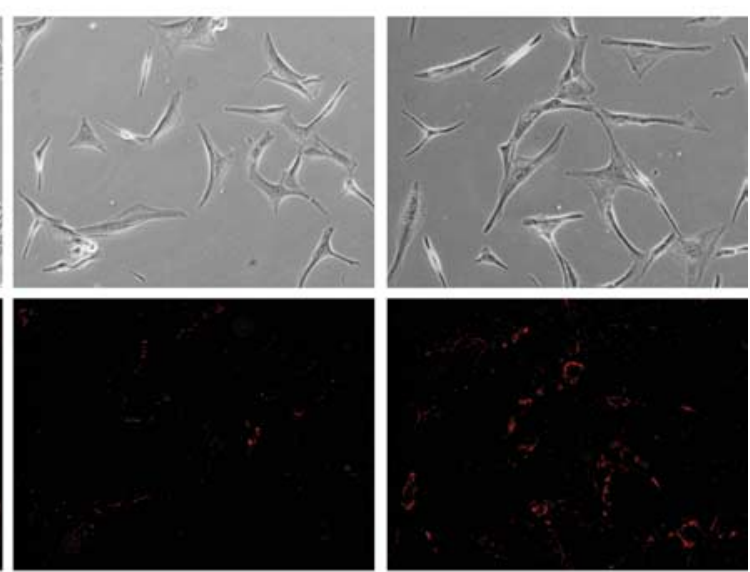

GGA (-)

\section{$\mathrm{H}_{2} \mathrm{O}_{2} 50 \mu \mathrm{M}$}

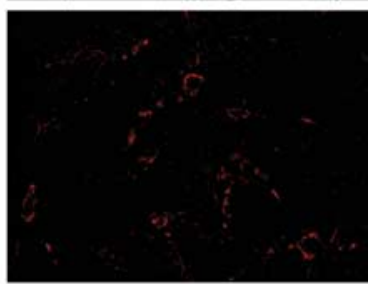

GGA $10 \mu \mathrm{M}$

5

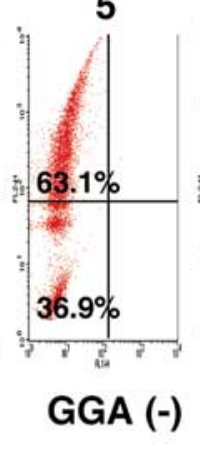

6

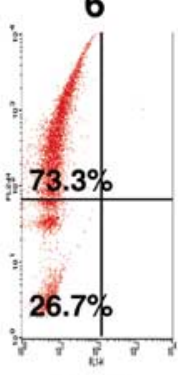

GGA $10 \mu \mathrm{M}$

\section{cell + beads} $+\mathrm{H}_{2} \mathrm{O}_{2} 50 \mu \mathrm{M}$

Figure 8. Effect of GGA on phagocytotic activity of cultured RPE cells. $\boldsymbol{A}$, Representative phase-contrast microscopy (top row) and fluorescence microscopy (bottom row) of human K-1034 RPE cells treated with latex beads (red dots). The control cells (left), $\mathrm{H}_{2} \mathrm{O}_{2}$-treated and GGA-untreated cells (center), and $\mathrm{H}_{2} \mathrm{O}_{2}$-treated and $\mathrm{GGA}$-treated cells (right) are shown. $\boldsymbol{B}$, Quantification of latex bead incorporation into the cells by flow cytometry. In this measurement, free latex beads are excluded from the gate (panel 1), and almost all cells (>99\%) not containing latex beads are gated into the lower left region (panel 2). $\mathrm{H}_{2} \mathrm{O}_{2}$-untreated and saline-pretreated (panel 3) or GGA-pretreated (panel 4) cells and $\mathrm{H}_{2} \mathrm{O}_{2}$-treated saline (panel 5) or GGA-pretreated (panel 6) cells are shown. $x$-axis, FL- $1 H$; $y$-axis, FL-2H.

pretreatment on phagocytotic activity of RPE in an in vitro model in which latex beads were incorporated into K-1034 cells. After incubation with red fluorescent-labeled latex beads, the incorporated latex beads were observed as red dots in the cell body of the $\mathrm{K}-1034$ cells (Fig. $8 \mathrm{~A}$, bottom left) with a fluorescence microscopy. When the cells were treated with a sublethal dose of $\mathrm{H}_{2} \mathrm{O}_{2}$ before the addition of the latex beads, this incorporation decreased (Fig. $8 \mathrm{~A}$, bottom center), and GGA pretreatment before $\mathrm{H}_{2} \mathrm{O}_{2}$ treatment counteracted the $\mathrm{H}_{2} \mathrm{O}_{2}$-induced diminution of the latex bead incorporation (Fig. $8 \mathrm{~A}$, bottom right). We further quantified the incorporation of latex beads into K-1034 cells using flow cytometry. In $\mathrm{H}_{2} \mathrm{O}_{2}$-untreated cells, the percentage of cells incorporating latex beads (high-FL-2 intensity) was almost $80 \%$ in both the GGA-treated and -untreated cells (Fig. 8 B, panels 3 and 4, respectively). In the $\mathrm{H}_{2} \mathrm{O}_{2}$-treated cells, the percentages were 63 and $73 \%$, respectively, in GGA-untreated (Fig. $8 B$, panel 5) and GGA-pretreated (Fig. $8 \mathrm{~B}$, panel 6) cells. In $\mathrm{H}_{2} \mathrm{O}_{2}$ treated cells, the mean $( \pm \mathrm{SD})$ percentages of cells incorporating latex beads from three independent experiments were $63.7 \pm 0.6$ and $72.7 \pm 1.6 \%$ in GGA-untreated and -pretreated cells, respectively $(p<0.01$ by unpaired $t$ test).

To determine whether Trx plays a role in GGA-mediated protection of phagocytotic activity, the ability of latex beads to be incorporated was analyzed in K-1034 cells overexpressing GFP-Trx fusion protein. Under fluorescence microscopy, incorporation of latex beads after $\mathrm{H}_{2} \mathrm{O}_{2}$ treatment seemed higher in cells with high-Trx expression (strongly labeled green cells indicated by arrow) compared with cells with low-Trx expression (Fig. $9 A$, arrowheads indicate low or no greenlabeled cells). In $\mathrm{H}_{2} \mathrm{O}_{2}$-untreated cells, the percentage of cells incorporating latex beads was almost $80 \%$ in populations with both low- and high-Trx expression (Fig. $9 \mathrm{C}$, left). In $\mathrm{H}_{2} \mathrm{O}_{2}$-treated cells, this percentage decreased to $70 \%$ in populations with low-Trx expression and was $80 \%$ in populations with high-Trx expression (Fig. 9C, right). This result of a higher percentage of cells incorporating latex beads in populations with high-Trx expression compared with that in populations with low-Trx expression was consistent with another transfection experiment.

\section{Discussion}

Oral treatment with GGA $1.0 \mathrm{mg} /$ mouse, corresponding to $50 \mathrm{mg} / \mathrm{kg}$ for $5 \mathrm{~d}$, markedly induced Trx and Hsp72 in RPE and slightly induced Trx in the neural retina (Figs. 1,2). Hsp72 induction was observed in the GCL and IPL by immunohistochemistry (Fig. $1 D)$ but not in the neural retina by Western blotting (Fig. 2B). In rat retinal ganglion cells, Hsp72 induction was seen after intraperitoneal injection of GGA $200 \mathrm{mg} / \mathrm{kg}$ daily for $>3 \mathrm{~d}$ (Ishii et al., 2003). Dilution of the signal in those specific layers because of the whole retinal analysis in Western blotting may explain the discrepancy in Hsp72 expression in the neural retina in this study.

The in vivo effect of GGA on Trx induction has not been studied extensively. In rat hearts, one oral GGA treatment of 200 $\mathrm{mg} / \mathrm{kg}$ did not induce Trx, whereas $50 \mathrm{mg} / \mathrm{kg}$ GGA induced Hsp72 (Ooie et al., 2001). Thus, the potential for GGA-mediated induction seems to differ between Hsp72 and Trx in each tissue. Preferential induction of Trx in the RPE layer was observed after light exposure in mice (Tanito et al., 2002a) or ischemia reperfusion in rats (Ohira et al., 1994). The RPE may be susceptible to GGA-mediated induction of Trx, which suggests that Trx plays a role in RPE cell function.

The Trx promoter region contains several conserved sequences for transcription factors such as the oxidative stress responsive element (ORE) (Taniguchi et al., 1996), antioxidant responsive element (ARE) (Kim et al., 2001), and the cAMP responsive element (Bai et al., 2003). ORE is thought to be not directly involved in GGA-mediated Trx induction, because $\mathrm{N}$-acetylcysteine, a potent antioxidant, had no effect on GGA- 
mediated Trx induction (Hirota et al., 2000). In erythroleukemic K-562 cells, Trx induction by hemin was mediated by ARE, whereas both heat shock factor (HSF)-1 and -2 were not involved in this induction, and no typical sequence for HSF binding was identified in the Trx gene (Kim et al., 2001). Because GGA enhances PG production (Terano et al., 1986) and PG E1 accelerates Trx induction in RPE cells through the cAMP-dependent pathway (Yamamoto et al., 1997a), a soluble factor such as PG may play a role in Trx induction. GGA-specific binding protein was reported in the cytosol of gastric mucosal cells (Hassan et al., 1998), although the details of this protein are essentially unknown. The mechanisms of Trx induction by GGA and the significance of simultaneous induction of Hsp72 and Trx by GGA in RPE, as observed in this study, remain to be clarified.

Compared with GGA-untreated mice, reduction of photoreceptor cell nuclei and expression of TUNEL-positive cells after light exposure were significantly precluded in GGA-pretreated mice (Fig. 3). The retinal function estimated by ERG was preserved in GGA-treated mice compared with GGA-untreated mice after light exposure (Fig. 4), suggesting that GGA pretreatment attenuates lightinduced retinal damage morphologically and functionally. The anti-apoptotic effects of GGA were previously reported in the ethanol- and $\mathrm{H}_{2} \mathrm{O}_{2}$-induced cultured rat hepatocyte injury (Mizushima et al., 1999) and in the ethanol-induced cultured guinea pig gastric mucosal cell injury (Ikeyama et al., 2001). The present study showed the anti-apoptotic effects of GGA in a model of light-induced photoreceptor cell damage.

The RPE cell layer is crucial for the maintenance and survival of adjacent photoreceptor cells via phagocytosis of the photoreceptor outer segments, regeneration of visual pigment, and trophic support by production of neurotrophic factors (Pacione et al., 2003; Schlingemann, 2004). Because Trx and Hsp72 were induced predominantly in the RPE layer, the protective effect of GGA may contribute to the protection and/or modulation of RPE functions.

Discs of photoreceptor outer segments are renewed constantly at a rate of $10 \%$ per day (Pacione et al., 2003), and this rate was remarkably accelerated by light exposure (Blanks et al., 1992). Failure of phagocytosis by the RPE leads to accumulation of outer segment debris in the subretinal space, and there is a resultant acceleration of photoreceptor cell loss as shown in rats with photoreceptor degeneration resulting from MERTK gene mutation (Bok and Hall, 1971; D'Cruz et al., 2000). In the present study, a sublethal dose of $\mathrm{H}_{2} \mathrm{O}_{2}$ diminished latex-bead incorporation into the RPE cells (Fig. 8). Pretreatment with GGA (Fig. 8) and overexpression of Trx (Fig. 9) counteracted the $\mathrm{H}_{2} \mathrm{O}_{2}$-induced diminution of latex-bead incorporation. Along with the differentia-
B
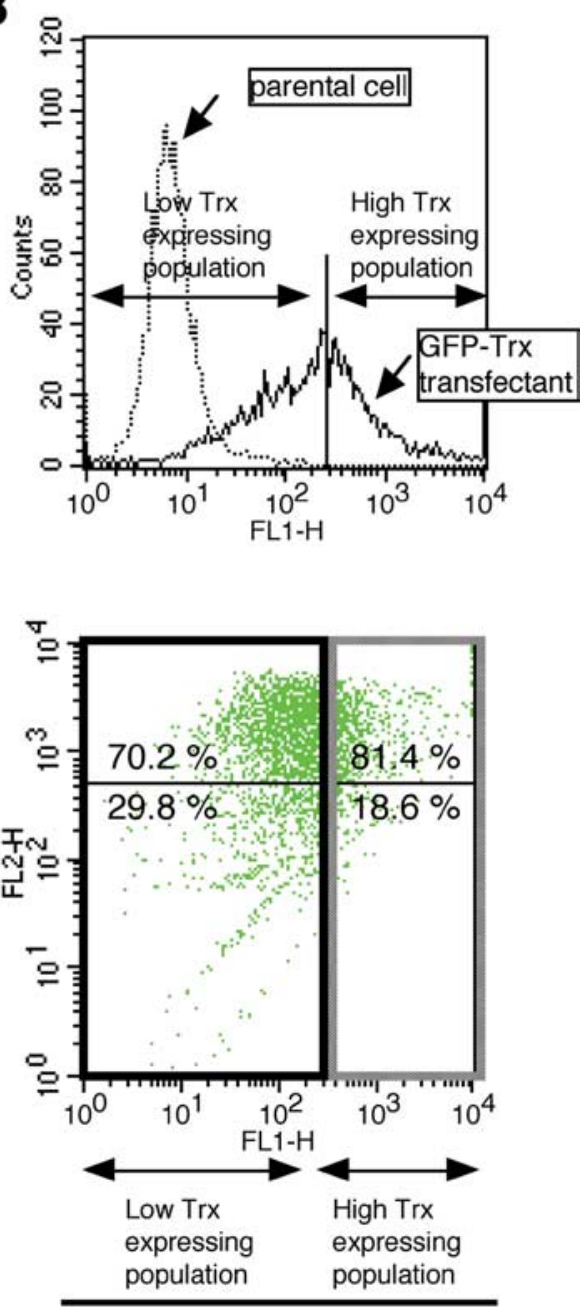

cell + beads $+\mathrm{H}_{2} \mathrm{O}_{2} 50 \mu \mathrm{M}$

Figure 9. Effect of Trx overexpression on phagocytotic activity of RPE cells. $\boldsymbol{A}$, Fluorescence microscopy in $\mathrm{H}_{2} \mathrm{O}_{2}$-pretreated referring to the upper limit of FL-1H intensity in parental nontransfected K-1034 cells. C, Quantification of latex bead incorporation into the cells by flow cytometry. $\mathrm{H}_{2} \mathrm{O}_{2}$-untreated (left) and $\mathrm{H}_{2} \mathrm{O}_{2}$-treated (right) cells are shown. $x$-axis, FL-1H; $y$-axis, FL-2H.

tion of murine monocytic M1 cells by interleukin-6 treatment, Trx may play a crucial role in regulating the intracellular oxidative stress level and increased phagocytotic activity (Takashima et al., 1999). Our results suggest that protection of the phagocytotic activity of RPE cells via Trx upregulation in RPE cells is a mechanism of GGA-mediated photoreceptor cell protection. GGA could upregulate PGs (Terano et al., 1986), and PGs (especially PGD2) counteract melatonin-mediated inhibition of phagocytosis activity in cultured RPE cells (Ogino et al., 1983), although PGs inhibit phagocytosis (Ogino et al., 1983; Ershov et al., 2000). Accordingly, PG-mediated regulation of phagocytotic activity may be involved in the mechanism of Trx- and GGA-mediated protection of phagocytotic activity against oxidative stress. Because the levels of $\mathrm{Hsp} 72$ contribute to the increased resistance to $\mathrm{H}_{2} \mathrm{O}_{2}$-mediated cell damage in cultured RPE cells (Bailey et al., 2004), and because Hsp72 is stimulated in macrophages that are actively engaged in phagocytosis (Kantengwa and Polla, 1993), Hsp72 induced in the RPE may be involved in GGA-mediated protection of phagocytotic activity against oxidative stress.

With GGA treatment, the increase in Trx was seen in both cell 
lysate and culture medium of RPE cells, whereas Hsp72 increased only in cell lysate (Fig. $6 A-C$ ). It is reported that only $5-15 \mathrm{pg}$ of Hsp72 is released per $1 \times 10^{6}$ glioma cells per day (Guzhova et al., 2001). Accordingly, our result that Hsp72 in culture medium was below the sensitivity of Western blots is in line with previous study. Upregulation of Trx, but not Hsp72, also was observed in neural retinas from GGA-treated mice (Fig. $2 B$ ), although the increments in Trx labeling with GGA treatment were not observed in neural retina by immunohistochemistry (Fig. $1 B$ ). This discrepancy in Trx induction in the neural retina in vivo may be the result of the loss of free Trx from the specimen in the process of sample preparation or staining, such as dehydration and deparaffinization. Accordingly, our observations suggest that RPE cells may release Trx. Trx scavenges singlet oxygen and hydroxyl radicals by itself (Das and Das, 2000) and $\mathrm{H}_{2} \mathrm{O}_{2}$ in association with Prx (Chae et al., 1994). Extracellular Trx prevents $\mathrm{H}_{2} \mathrm{O}_{2}$-induced cell damage in cultured photoreceptor cells (Fig. $6 D)$. Prx family proteins were expressed in the neural retina and RPE (Fig. 7). Expressions of $8 \mathrm{OHdG}$, a major DNA basemodified product that is induced by the hydroxyl radical, singlet oxygen, or photodynamic action (Shibutani et al., 1991), and 4HNE-modified protein, stable Michael adducts formed from a reaction between a major final product of lipid peroxidation with established cytotoxicity and mutagenicity and histidyl, lysyl, or cysteinyl residues of proteins (Uchida and Stadtman, 1992), were remarkably inhibited by GGA treatment in the retina (Fig. 5A,B). Collectively, Trx released from the RPE cells contributes to the cytoprotection of photoreceptor cells by eliminating oxidative stress. The RPE releases several neurotrophic factors such as nerve growth factor (NGF), brain-derived growth factor, neurotrophin-3 (Ishida et al., 1997), and pigment epitheliumderived factor (Jablonski et al., 2000). These neurotrophic factors confer cytoprotection against light-induced photoreceptor cell damage (LaVail et al., 1992; Cao et al., 2001). Trx is essential for the NGF-mediated neurite outgrowth in neuronal PC12 cells (Bai et al., 2003). Trx induced in the RPE contributes to cytoprotection against ischemia-reperfusion injury of the inner retina in rats (Yamamoto et al., 1997b). Together, our results strongly suggest that Trx is a neurotrophic factor released from RPE cells that plays a crucial role in maintaining photoreceptor cell integrity against photooxidative insults. Although the precise mechanism in leaderless release of Trx from cells is currently unknown, the redox status of tissues or cells is deeply involved in the mechanism (Kondo et al., 2004).

Attenuation of oxidative stress by GGA, per se, also may explain GGA-mediated cytoprotection. However, the GGA concentration in blood reaches the highest level after $5 \mathrm{~h}$ of oral treatment and thereafter returns rapidly to the pretreatment level (data sheet on Selbex; Eisai), and a direct scavenging effect of GGA against free radicals has not been reported. In addition, it is possible that other neuroprotective molecules other than Trx and Hsp72, such as neurotrophic factors, are involved in the GGAmediated cytoprotection. GGA has been used as an antigastric ulcer drug in Japan, and few adverse effects have been reported in the clinical experiments with GGA. Intensification of endogenous Trx by treatment with GGA may be a useful strategy to prevent photooxidative stress-related retinal diseases.

In summary, GGA administration upregulates Trx and Hsp72 mainly in the RPE layer and mediates cytoprotection against lightinduced photoreceptor cell damage in mice. Protection of phagocytotic activity through induction of Trx and release of Trx from RPE cells may be a mechanism of GGA-mediated cytoprotection.

\section{References}

Bai J, Nakamura H, Hattori I, Tanito M, Yodoi J (2002) Thioredoxin suppresses 1-methyl-4-phenylpyridinium-induced neurotoxicity in rat PC12 cells. Neurosci Lett 321:81-84.

Bai J, Nakamura H, Kwon YW, Hattori I, Yamaguchi Y, Kim YC, Kondo N, Oka S, Ueda S, Masutani H, Yodoi J (2003) Critical roles of thioredoxin in nerve growth factor-mediated signal transduction and neurite outgrowth in PC12 cells. J Neurosci 23:503-509.

Bailey TA, Kanuga N, Romero IA, Greenwood J, Luthert PJ, Cheetham ME (2004) Oxidative stress affects the junctional integrity of retinal pigment epithelial cells. Invest Ophthalmol Vis Sci 45:675-684.

Barbe MF, Tytell M, Gower DJ, Welch WJ (1988) Hyperthermia protects against light damage in the rat retina. Science 241:1817-1820.

Bilski J, Murty VL, Nadziejko C, Sarosiek J, Aono M, Moriga M, Slomiany A, Slomiany BL (1988) Protection against alcohol-induced gastric mucosal injury by geranylgeranylacetone: effect of indomethacin. Digestion 41:22-33.

Blanks JC, Pickford MS, Organisciak DT (1992) Ascorbate treatment prevents accumulation of phagosomes in RPE in light damage. Invest Ophthalmol Vis Sci 33:2814-2821.

Bok D, Hall MO (1971) The role of the pigment epithelium in the etiology of inherited retinal dystrophy in the rat. J Cell Biol 49:664-682.

Byrnes GA, Chang B, Loose I, Miller SA, Benson WE (1995) Prospective incidence of photic maculopathy after cataract surgery. Am J Ophthalmol 119:231-232.

Cao W, Tombran-Tink J, Elias R, Sezate S, Mrazek D, McGinnis JF (2001) In vivo protection of photoreceptors from light damage by pigment epithelium-derived factor. Invest Ophthalmol Vis Sci 42:1646-1652.

Chae HZ, Chung SJ, Rhee SG (1994) Thioredoxin-dependent peroxide reductase from yeast. J Biol Chem 269:27670-27678.

Cideciyan AV, Hood DC, Huang Y, Banin E, Li ZY, Stone EM, Milam AH, Jacobson SG (1998) Disease sequence from mutant rhodopsin allele to rod and cone photoreceptor degeneration in man. Proc Natl Acad Sci USA 95:7103-7108.

Cruickshanks KJ, Klein R, Klein BE (1993) Sunlight and age-related macular degeneration. The Beaver Dam eye study. Arch Ophthalmol 111:514-518.

Das KC, Das CK (2000) Thioredoxin, a singlet oxygen quencher and hydroxyl radical scavenger: redox independent functions. Biochem Biophys Res Commun 277:443-447.

D’Cruz PM, Yasumura D, Weir J, Matthes MT, Abderrahim H, LaVail MM, Vollrath D (2000) Mutation of the receptor tyrosine kinase gene Mertk in the retinal dystrophic RCS rat. Hum Mol Genet 9:645-651.

Dekigai H, Nakamura H, Bai J, Tanito M, Masutani H, Hirota K, Matsui H, Murakami M, Yodoi J (2001) Geranylgeranylacetone promotes induction and secretion of thioredoxin in gastric mucosal cells and peripheral blood lymphocytes. Free Radic Res 35:23-30.

Ershov AV, Parkins N, Lukiw WJ, Bazan NG (2000) Modulation of early response gene expression by prostaglandins in cultured rat retinal pigment epithelium cells. Curr Eye Res 21:968-974.

Feldman DE, Frydman J (2000) Protein folding in vivo: the importance of molecular chaperones. Curr Opin Struct Biol 10:26-33.

Fujii T, Fujii J, Taniguchi N (2001) Augmented expression of peroxiredoxin VI in rat lung and kidney after birth implies an antioxidative role. Eur J Biochem 268:218-225.

Gauntt CD, Ohira A, Honda O, Kigasawa K, Fujimoto T, Masutani H, Yodoi J, Honda Y (1994) Mitochondrial induction of adult T cell leukemia derived factor $(\mathrm{ADF} / \mathrm{hTx})$ after oxidative stresses in retinal pigment epithelial cells. Invest Ophthalmol Vis Sci 35:2916-2923.

Goncalves NS, Hale C, Dougan G, Frankel G, MacDonald TT (2003) Binding of intimin from enteropathogenic Escherichia coli to lymphocytes and its functional consequences. Infect Immun 71:2960-2965.

Guzhova I, Kislyakova K, Moskaliova O, Fridlanskaya I, Tytell M, Cheetham M, Margulis B (2001) In vitro studies show that $\mathrm{Hsp} 70$ can be released by glia and that exogenous Hsp70 can enhance neuronal stress tolerance. Brain Res 914:66-73.

Hafezi F, Steinbach JP, Marti A, Munz K, Wang ZQ, Wagner EF, Aguzzi A, Reme CE (1997) The absence of c-fos prevents light-induced apoptotic cell death of photoreceptors in retinal degeneration in vivo. Nat Med 3:346-349.

Hassan S, Kinoshita Y, Okada A, Maekawa T, Fukui H, Chiba T (1998) Geranylgeranylacetone, an anti-ulcer drug, stimulates hexosamine production in a rat gastric mucosal cell line through binding to a specific cytosolic protein. J Gastroenterol Hepatol 13:809-815. 
Hirakawa T, Rokutan K, Nikawa T, Kishi K (1996) Geranylgeranylacetone induces heat shock proteins in cultured guinea pig gastric mucosal cells and rat gastric mucosa. Gastroenterology 111:345-357.

Hirota K, Murata M, Sachi Y, Nakamura H, Takeuchi J, Mori K, Yodoi J (1999) Distinct roles of thioredoxin in the cytoplasm and in the nucleus. A two-step mechanism of redox regulation of transcription factor NF- $\kappa$ B. J Biol Chem 274:27891-27897.

Hirota K, Nakamura H, Arai T, Ishii H, Bai J, Itoh T, Fukuda K, Yodoi J (2000) Geranylgeranylacetone enhances expression of thioredoxin and suppresses ethanol-induced cytotoxicity in cultured hepatocytes. Biochem Biophys Res Commun 275:825-830.

Holmgren A (1985) Thioredoxin. Annu Rev Biochem 54:237-271.

Ikeyama S, Kusumoto K, Miyake H, Rokutan K, Tashiro S (2001) A nontoxic heat shock protein 70 inducer, geranylgeranylacetone, suppresses apoptosis of cultured rat hepatocytes caused by hydrogen peroxide and ethanol. J Hepatol 35:53-61.

Ishida K, Yoshimura N, Yoshida M, Honda Y, Murase K, Hayashi K (1997) Expression of neurotrophic factors in cultured human retinal pigment epithelial cells. Curr Eye Res 16:96-101.

Ishii Y, Kwong JM, Caprioli J (2003) Retinal ganglion cell protection with geranylgeranylacetone, a heat shock protein inducer, in a rat glaucoma model. Invest Ophthalmol Vis Sci 44:1982-1992.

Jablonski MM, Tombran-Tink J, Mrazek DA, Iannaccone A (2000) Pigment epithelium-derived factor supports normal development of photoreceptor neurons and opsin expression after retinal pigment epithelium removal. J Neurosci 20:7149-7157.

Kantengwa S, Polla BS (1993) Phagocytosis of Staphylococcus aureus induces a selective stress response in human monocytes-macrophages ( $\mathrm{M} \mathrm{phi):} \mathrm{modu-}$ lation by M phi differentiation and by iron. Infect Immun 61:1281-1287.

Kigasawa K, Soushi S, Tanaka Y, Obazawa H (1994) Morphologic and chromosomal study of a human retinal pigment epithelial cell line. Jpn J Ophthalmol 38:10-15.

Kim YC, Masutani H, Yamaguchi Y, Itoh K, Yamamoto M, Yodoi J (2001) Hemin-induced activation of the thioredoxin gene by Nrf2. A differential regulation of the antioxidant responsive element by a switch of its binding factors. J Biol Chem 276:18399-18406.

Kondo N, Ishii Y, Kwon YW, Tanito M, Horita H, Nishinaka Y, Nakamura H, Yodoi J (2004) Redox-sensing release of human thioredoxin from T lymphocytes with negative feedback loops. J Immunol 172:442-448.

Kwon YW, Ueda S, Ueno M, Yodoi J, Masutani H (2002) Mechanism of p53dependent apoptosis induced by 3-methylcholanthrene: involvement of p53 phosphorylation and p38 MAPK. J Biol Chem 277:1837-1844.

LaVail MM, Unoki K, Yasumura D, Matthes MT, Yancopoulos GD, Steinberg RH (1992) Multiple growth factors, cytokines, and neurotrophins rescue photoreceptors from the damaging effects of constant light. Proc Natl Acad Sci USA 89:11249-11253.

Matsumoto A, Okado A, Fujii T, Fujii J, Egashira M, Niikawa N, Taniguchi N (1999) Cloning of the peroxiredoxin gene family in rats and characterization of the fourth member. FEBS Lett 443:246-250.

Mizushima T, Tsutsumi S, Rokutan K, Tsuchiya T (1999) Suppression of ethanol-induced apoptotic DNA fragmentation by geranylgeranylacetone in cultured guinea pig gastric mucosal cells. Dig Dis Sci 44:510-514.

Murakami M, Muto Y, Moriwaki H, Ohgo T (1981) Effect of acyclic polyisoprenoids on the biosynthesis of mannose-labeled glycolipids in rat liver microsomes. Biochem Biophys Res Commun 103:706-712.

Nakamura H, Nakamura K, Yodoi J (1997) Redox regulation of cellular activation. Annu Rev Immunol 15:351-369.

Nakamura H, De Rosa SC, Yodoi J, Holmgren A, Ghezzi P, Herzenberg LA (2001) Chronic elevation of plasma thioredoxin: inhibition of chemotaxis and curtailment of life expectancy in AIDS. Proc Natl Acad Sci USA 98:2688-2693.

Ogino N, Matsumura M, Shirakawa H, Tsukahara I (1983) Control mechanism of phagocytic activity of retinal pigment epithelial cells. I. Nippon Ganka Gakkai Zasshi 87:445-455.

Ohira A, Honda O, Gauntt CD, Yamamoto M, Hori K, Masutani H, Yodoi J, Honda Y (1994) Oxidative stress induces adult T cell leukemia derived factor/thioredoxin in the rat retina. Lab Invest 70:279-285.

Ooie T, Takahashi N, Saikawa T, Nawata T, Arikawa M, Yamanaka K, Hara M, Shimada T, Sakata T (2001) Single oral dose of geranylgeranylacetone induces heat-shock protein 72 and renders protection against ischemia/reperfusion injury in rat heart. Circulation 104:1837-1843.
Organisciak DT, Wang HM, Xie A, Reeves DS, Donoso LA (1989) Intenselight mediated changes in rat rod outer segment lipids and proteins. Prog Clin Biol Res 314:493-512.

Pacione LR, Szego MJ, Ikeda S, Nishina PM, McInnes RR (2003) Progress toward understanding the genetic and biochemical mechanisms of inherited photoreceptor degenerations. Annu Rev Neurosci 26:657-700.

Ranchon I, LaVail MM, Kotake Y, Anderson RE (2003) Free radical trap phenyl- $N$-tert-butylnitrone protects against light damage but does not rescue $\mathrm{P} 23 \mathrm{H}$ and $\mathrm{S} 334$ ter rhodopsin transgenic rats from inherited retinal degeneration. J Neurosci 23:6050-6057.

Saitoh M, Nishitoh H, Fujii M, Takeda K, Tobiume K, Sawada Y, Kawabata M, Miyazono K, Ichijo H (1998) Mammalian thioredoxin is a direct inhibitor of apoptosis signal-regulating kinase (ASK) 1. EMBO J 17:2596-2606.

Schlingemann RO (2004) Role of growth factors and the wound healing response in age-related macular degeneration. Graefes Arch Clin Exp Ophthalmol 242:91-101.

Shibutani S, Takeshita M, Grollman AP (1991) Insertion of specific bases during DNA synthesis past the oxidation-damaged base 8-oxodG. Nature 349:431-434.

Tagaya Y, Maeda Y, Mitsui A, Kondo N, Matsui H, Hamuro J, Brown N, Arai K, Yokota T, Wakasugi H (1989) ATL-derived factor (ADF), an IL-2 receptor/ Tac inducer homologous to thioredoxin: possible involvement of dithiolreduction in the IL-2 receptor induction. EMBO J 8:757-764.

Takashima Y, Hirota K, Nakamura H, Nakamura T, Akiyama K, Cheng FS, Maeda M, Yodoi J (1999) Differential expression of glutaredoxin and thioredoxin during monocytic differentiation. Immunol Lett 68:397-401.

Tan E, Ding XQ, Saadi A, Agarwal N, Naash MI, Al-Ubaidi MR (2004) Expression of cone-photoreceptor-specific antigens in a cell line derived from retinal tumors in transgenic mice. Invest Ophthalmol Vis Sci 45:764-768.

Taniguchi Y, Taniguchi-Ueda Y, Mori K, Yodoi J (1996) A novel promoter sequence is involved in the oxidative stress-induced expression of the adult T-cell leukemia-derived factor (ADF)/human thioredoxin (Trx) gene. Nucleic Acids Res 24:2746-2752.

Tanito M, Masutani H, Nakamura H, Ohira A, Yodoi J (2002a) Cytoprotective effect of thioredoxin against retinal photic injury in mice. Invest Ophthalmol Vis Sci 43:1162-1167.

Tanito M, Masutani H, Nakamura H, Oka S, Ohira A, Yodoi J (2002b) Attenuation of retinal photooxidative damage in thioredoxin transgenic mice. Neurosci Lett 326:142-146.

Tanito M, Nishiyama A, Tanaka T, Masutani H, Nakamura H, Yodoi J, Ohira A (2002c) Change of redox status and modulation by thiol replenishment in retinal photooxidative damage. Invest Ophthalmol Vis Sci 43:2392-2400.

Terano A, Shiga J, Hiraishi H, Ota S, Sugimoto T (1986) Protective action of tetraprenylacetone against ethanol-induced damage in rat gastric mucosa. Digestion 35:182-188.

Toyokuni S, Uchida K, Okamoto K, Hattori-Nakakuki Y, Hiai H, Stadtman ER (1994) Formation of 4-hydroxy-2-nonenal-modified proteins in the renal proximal tubules of rats treated with a renal carcinogen, ferric nitrilotriacetate. Proc Natl Acad Sci USA 91:2616-2620.

Toyokuni S, Tanaka T, Hattori Y, Nishiyama Y, Yoshida A, Uchida K, Hiai H, Ochi H, Osawa T (1997) Quantitative immunohistochemical determination of 8 -hydroxy-2'-deoxyguanosine by a monoclonal antibody N45.1: its application to ferric nitrilotriacetate-induced renal carcinogenesis model. Lab Invest 76:365-374.

Uchida K, Stadtman ER (1992) Modification of histidine residues in proteins by reaction with 4-hydroxynonenal. Proc Natl Acad Sci USA 89:4544-4548.

Wenzel A, Grimm C, Marti A, Kueng-Hitz N, Hafezi F, Niemeyer G, Reme CE (2000) c-fos controls the "private pathway" of light-induced apoptosis of retinal photoreceptors. J Neurosci 20:81-88.

Yamamoto M, Sato N, Tajima H, Furuke K, Ohira A, Honda Y, Yodoi J (1997a) Induction of human thioredoxin in cultured human retinal pigment epithelial cells through cyclic AMP-dependent pathway: involvement in the cytoprotective activity of prostaglandin E1. Exp Eye Res 65:645-652.

Yamamoto M, Ohira A, Honda O, Sato N, Furuke K, Yodoi J, Honda Y (1997b) Analysis of localization of adult T-cell leukemia-derived factor in the transient ischemic rat retina after treatment with OP-1206 alphaCD, a prostaglandin E1 analogue. J Histochem Cytochem 45:63-70.

Yu Q, Kent CR, Tytell M (2001) Retinal uptake of intravitreally injected Hsc/ Hsp70 and its effect on susceptibility to light damage. Mol Vis 7:48-56. 